
Units in the Nutrient Enrichment Effects Topical Study of the National Water-Quality Assessment Program

Data Series 306

U.S. Department of the Interior U.S. Geological Survey 



\section{Riparian Land Use/Land Cover Data for Five Study Units in the Nutrient Enrichment Effects Topical Study of the National Water-Quality Assessment Program}

By Michaela R. Johnson, Gary R. Buell, Moon H. Kim, and Mark R. Nardi

Prepared as part of National Water-Quality Assessment Program

Data Series 306 


\section{U.S. Department of the Interior DIRK KEMPTHORNE, Secretary}

\section{U.S. Geological Survey \\ Mark D. Myers, Director}

\section{U.S. Geological Survey, Reston, Virginia: 2007}

For product and ordering information:

World Wide Web: http://www.usgs.gov/pubprod

Telephone: 1-888-ASK-USGS

For more information on the USGS — the Federal source for science about the Earth, its natural and living resources, natural hazards, and the environment:

World Wide Web: http://www.usgs.gov

Telephone: 1-888-ASK-USGS

Any use of trade, product, or firm names is for descriptive purposes only and does not imply endorsement by the U.S. Government.

Although this report is in the public domain, permission must be secured from the individual copyright owners to reproduce any copyrighted materials contained within this report.

Suggested citation:

Johnson, M.R., Buell, G.R., Kim, M.H., and Nardi, M.R., 2007, Riparian land use/land cover data for five study units in the Nutrient Enrichment Effects Topical study of the National Water-Quality Assessment Program: U.S. Geological Survey Data Series 306, 9 p. 


\section{Contents}

Abstract
Introduction
Purpose and Scope
Acknowledgments
Methodology
Riparian Land Use/Land Cover Data
References Cited

\section{Figure}

1. Map showing locations of five National Water-Quality Assessment Program study units and riparian mapping locations in the contiguous United States used to delineate land use/land cover for Nutrient Enrichment Effects Topical study, 2003-2004 ...............2

\section{Tables}

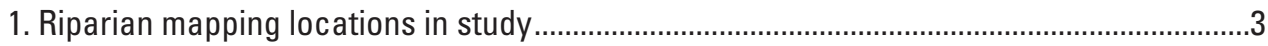

2. Land-use/land-cover classification system.......................................................................

\section{Conversion Factors and Datum}

\begin{tabular}{lcl}
\hline \multicolumn{1}{c}{ Multiply } & By & To obtain \\
\hline & Length & \\
\hline meter $(\mathrm{m})$ & 3.281 & foot (ft) \\
kilometer $(\mathrm{km})$ & 0.6214 & mile (mi) \\
\hline
\end{tabular}

Horizontal coordinate information is referenced to the North American Datum of 1983 (NAD 83). 


\section{Abbreviations and Acronyms (additional information noted in parentheses)}

$\begin{array}{ll}\text { ACFB } & \text { Apalachicola-Chattahoochee-Flint River Basin (study unit) } \\ \text { CCYK } & \text { Central Columbia Plateau - Yakima River Basin (study unit) } \\ \text { CNBR } & \text { Central Nebraska Basins (study unit) } \\ \text { DEM } & \text { digital elevation model } \\ \text { DOQQ } & \text { digital orthophoto quarter-quadrangle } \\ \text { ESRI } & \text { Environmental Research Systems Institute, Inc. (Redlands, Calif.) } \\ \text { GIS } & \text { geographic information system } \\ \text { LULC } & \text { land use/land cover } \\ \text { NAPP } & \text { National Aerial Photography Program } \\ \text { NAWQA } & \text { National Water-Quality Assessment (Program) } \\ \text { NEET } & \text { Nutrient Enrichment Effects Topical (study) } \\ \text { NHD } & \text { National Hydrography Dataset } \\ \text { NLCD } & \text { National Land Cover Dataset } \\ \text { NWI } & \text { National Wetlands Inventory } \\ \text { PODL } & \text { Potomac River Basin and Delmarva Peninsula (study unit) } \\ \text { USGS } & \text { U.S. Geological Survey } \\ \text { WHMI } & \text { White, Great and Little Miami River Basins (study unit) }\end{array}$




\title{
Riparian Land Use/Land Cover Data for Five Study Units in the Nutrient Enrichment Effects Topical Study of the National Water-Quality Assessment Program
}

\author{
By Michaela R. Johnson, Gary R. Buell, Moon H. Kim, and Mark R. Nardi
}

\section{Abstract}

This dataset was developed as part of the National WaterQuality Assessment (NAWQA) Program, Nutrient Enrichment Effects Topical (NEET) study for five study units distributed across the United States: Apalachicola-Chattahoochee-Flint River Basin, Central Columbia Plateau-Yakima River Basin, Central Nebraska Basins, Potomac River Basin and Delmarva Peninsula, and White, Great and Little Miami River Basins. One hundred forty-three stream reaches were examined as part of the NEET study conducted 2003-04. Stream segments, with lengths equal to the logarithm of the basin area, were delineated upstream from the downstream ends of the stream reaches with the use of digital orthophoto quarter quadrangles (DOQQ) or selected from the high-resolution National Hydrography Dataset (NHD). Use of the NHD was necessary when the stream was not distinguishable in the DOQQ because of dense tree canopy. The analysis area for each stream segment was defined by a buffer beginning at the segment extending to 250 meters lateral to the stream segment. Delineation of land use/land cover (LULC) map units within stream segment buffers was conducted using on-screen digitizing of riparian LULC classes interpreted from the DOQQ. LULC units were mapped using a classification strategy consisting of nine classes. National Wetlands Inventory (NWI) data were used to aid in wetland classification. Longitudinal transect sampling lines offset from the stream segments were generated and partitioned into the underlying LULC types. These longitudinal samples yielded the relative linear extent and sequence of each LULC type within the riparian zone at the segment scale. The resulting areal and linear LULC data filled in the spatial-scale gap between the 30-meter resolution of the National Land Cover Dataset and the reach-level habitat assessment data collected onsite routinely for NAWQA ecological sampling. The final data consisted of 12 geospatial datasets: LULC within 25 meters of the stream reach (polygon); LULC within 50 meters of the stream reach (polygon); LULC within 50 meters of the stream segment (polygon); LULC within 100 meters of the stream segment (polygon); LULC within 150 meters of the stream segment (polygon);
LULC within 250 meters of the stream segment (polygon); frequency of gaps in woody vegetation LULC at the reach scale (arc); stream reaches ( $\operatorname{arc})$; longitudinal LULC at the reach scale (arc); frequency of gaps in woody vegetation LULC at the segment scale (arc); stream segments (arc); and longitudinal LULC at the segment scale (arc).

\section{Introduction}

Riparian habitat plays an important ecological role, providing connections among land-use activities, nutrient dynamics, and aquatic ecosystems. Thus, quantifying the riparian systems is critical to the success of the U.S. Geological Survey (USGS) National Water-Quality Assessment (NAWQA) Program, Nutrient Enrichment Effects Topical (NEET) study. Delineation of the extent and character of the riparian system and riparian woodland can aid understanding of their relative importance for different streams, facilitating comparisons. Encroachment of terrestrial land uses into the riparian zone also can be documented efficiently during the mapping of the riparian land use/land cover (LULC). The purpose of this NEET study component was to delineate and characterize LULC within the sampled riparian systems.

NAWQA uses a combined physical, chemical, and biological approach to assess the Nation's water quality in 42 major river-basin and aquifer systems. Habitat conditions are evaluated using a modified hierarchical system proposed by Frissell and others (1986) at four scales: (1) basin, (2) segment, (3) reach, and (4) microhabitat (Fitzpatrick and others, 1998). LULC data, primarily woody vegetation at the segment and reach scales, are being used to evaluate nutrientenrichment conditions for a subset of the NAWQA major river basins.

\section{Purpose and Scope}

This report provides riparian LULC data for five NEET study units distributed across the United States at the 
ecologically important scales of segments and reaches. These data were developed by following procedures outlined in the protocol by Johnson and Zelt (2005). The five study units were (1) the Apalachicola-Chattahoochee-Flint River Basin (ACFB) in Georgia and Florida, (2) the Central Columbia PlateauYakima River Basin (CCYK) in Washington, (3) the Central Nebraska Basins (CNBR) in Nebraska, (4) the Potomac River Basin and Delmarva Peninsula (PODL) in Delaware and Maryland, and (5) the White, Great and Little Miami River Basins (WHMI) in Indiana and Ohio (fig. 1). Specifically, this dataset provides information at a scale that fills in a data gap in riparian LULC between the land-cover data available at 30-m resolution from the 1990s National Land Cover Dataset (NLCD) (Vogelmann and others, 2001) and the reach-level data routinely collected for each NAWQA habitat assessment. During the reach-level habitat assessments, only the dominant LULC type within 30-m from the top of each streambank was recorded at 11 evenly spaced transects (Fitzpatrick and others, 1998). The riparian LULC data described in this report are used to support the USGS NAWQA Program.

\section{Acknowledgments}

Stephen J. Char (USGS Colorado Water Science Center) was instrumental in finalizing the geographic information system (GIS) datasets and metadata for publication. The authors wish to thank Naomi Nakagaki (USGS California Water Science Center) and James L. Kennedy (USGS Wisconsin Water Science Center) for their thoughtful and helpful reviews.

\section{Methodology}

The riparian LULC map unit delineation and classification of the sample of segments and reaches were determined for 143 sites using the methods documented by Johnson and Zelt (2005). Riparian mapping locations were the same sites where stream reaches were identified for NEET physical habitat sampling in 2003-04 (table 1).

NEET sites for each study unit were located within the study unit and targeted nutrient ecoregion boundaries, where possible, according to the site-selection procedures documented by Frankforter and others (2003). The nutrient ecoregions targeted for each study unit were ACFB-southern coastal plains, CCYK - xeric west, CNBR — south-central cultivated Great Plains, PODL-eastern coastal plains, and WHMI-Corn Belt and northern Great Plains (U.S. Environmental Protection Agency, 2002). In cases where a sufficient number of sampling sites were not available within the study unit boundary, locations outside the study unit but within the targeted nutrient ecoregion were allowed. Exceptions also were made for selected NAWQA national surface-water trends sites outside the nutrient ecoregion boundary (Gilliom and others, 2001).

Lengths of stream reaches at each of the 143 sites examined for the five NEET study units were variable and based on field conditions. Generally, the reach length is 20 times the mean wetted channel width (Fitzpatrick and others, 1998). Reach lengths ranged from 90 to 560 meters. Stream reaches were extracted from the downstream end of the delineated stream segments.

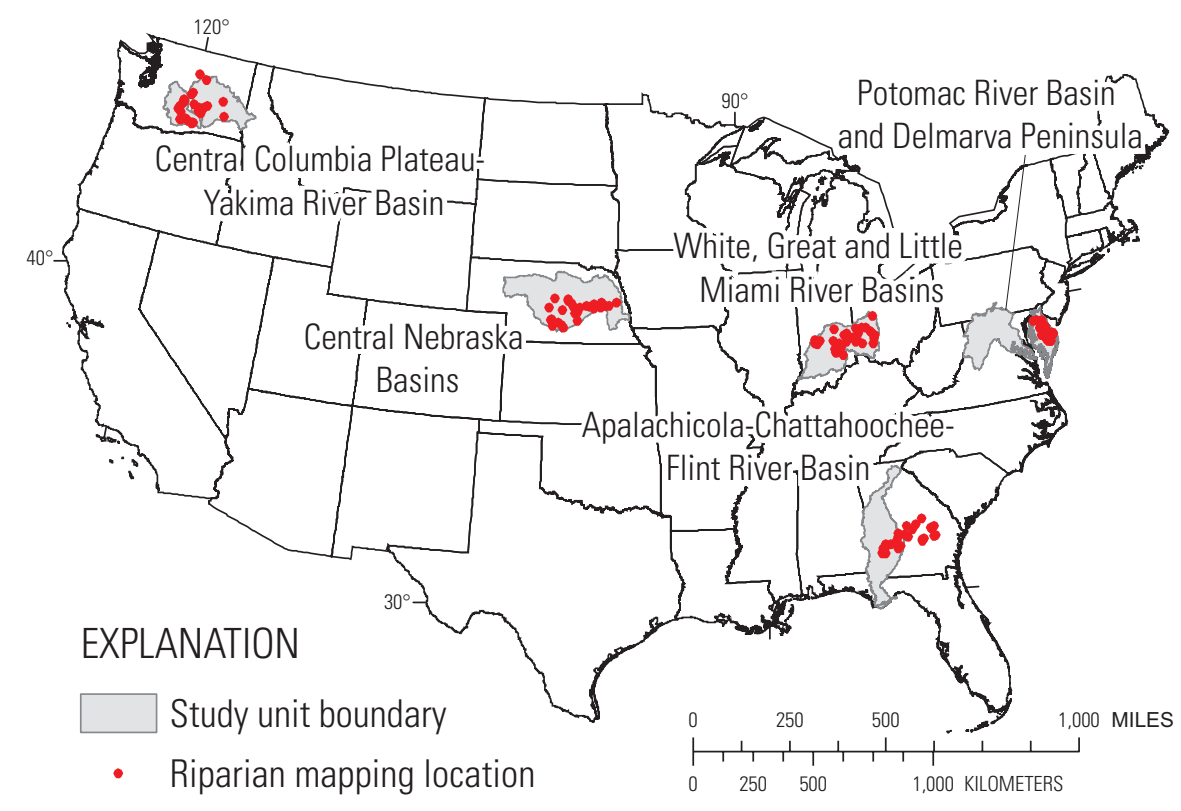

Figure 1. Locations of five National Water-Quality Assessment Program study units and riparian mapping locations in the contiguous United States used to delineate land use/land cover for the Nutrient Enrichment Effects Topical study, 2003-04. 
Table 1. Riparian mapping locations in study.

[CR, county road; DR, drain; JD, joint drain; SCBID, South Columbia Basin Irrigation District; SR, state road]

\begin{tabular}{|c|c|}
\hline U.S. Geological Survey station number & Station name \\
\hline \multicolumn{2}{|c|}{ Apalachicola-Chattahoochee-Flint River Basin } \\
\hline 02214315 & Savage Creek at CR 87 near Westlake, GA \\
\hline 02215120 & Cedar Creek at CR 198 near Hawkinsville, GA \\
\hline 02215295 & Bluff Creek at Laidler Road near Finleyson, GA \\
\hline 02215656 & Gum Swamp Creek at GA 126 near Cochran, GA \\
\hline 02216170 & Sugar Creek at CR 194 near Towns, GA \\
\hline 02216185 & Turnpike Creek at GA 149 near McRae, GA \\
\hline 02225148 & Ohoopee River at GA 57 near Wrightsville, GA \\
\hline 02225317 & Jacks Creek at CR 252 near Stillmore, GA \\
\hline 02225353 & Pendleton Creek at GA 297 near Vidalia, GA \\
\hline 02225365 & Tiger Creek at GA 297 near Vidalia, GA \\
\hline 02225600 & Rocky Creek at GA 147 near Johnson Corner, GA \\
\hline 02349685 & Hogcrawl Creek at GA 329 near Five Points, GA \\
\hline 02349900 & Turkey Creek at Byromville, GA \\
\hline 02351790 & Muckaloochee Creek at Cross Road near Sumter, GA \\
\hline 02353097 & Ichawaynochaway Creek at Cherry Cola Road near Dawson, GA \\
\hline 02353098 & Turkey Creek at Cherry Cola Road near Graves, GA \\
\hline 02353190 & Little Ichawaynochaway Creek at CR 3 near Cuthbert, GA \\
\hline 02353245 & Falling Creek at CR 149 near Morgan, GA \\
\hline 02353330 & Pachitla Creek Fountain Bridge Road near Carnegie, GA \\
\hline 02353360 & Carter Creek at CR 20 near Carnegie, GA \\
\hline \multicolumn{2}{|c|}{ Central Columbia Plateau-Yakima River Basin (CCYK) } \\
\hline 12437940 & East Foster Creek at Bell Butte Road near Leahy, WA \\
\hline 12449950 & Methow River near Pateros, WA \\
\hline 12462545 & Rock Island Creek near Rock Island, WA \\
\hline 12462640 & Colockum Creek near Rock Island, WA \\
\hline 12464606 & Sand Hollow Creek at S Road SW near Vantage, WA \\
\hline
\end{tabular}


Table 1. Riparian mapping locations in study.-Continued

[CR, county road; DR, drain; JD, joint drain; SCBID, South Columbia Basin Irrigation District; SR, state road]

\begin{tabular}{|c|c|}
\hline U.S. Geological Survey station number & Station name \\
\hline \multicolumn{2}{|c|}{ Central Columbia Plateau-Yakima River Basin (CСYK)—Continued } \\
\hline 12464770 & Crab Creek at Rocky Ford Road near Ritzville, WA \\
\hline 12472190 & Lower Crab Creek near McManamon Road near Othello, WA \\
\hline 12472380 & Crab Creek Lateral above Royal Lake near Othello, WA \\
\hline 12472940 & SCBID Wahatis Wasteway near Mattawa, WA \\
\hline 12473190 & Wahluke Branch 10 Wasteway near White Bluffs, WA \\
\hline 12483940 & Naneum Creek above Game Farm Road near Kittitas, WA \\
\hline 12485940 & Wenas Creek at Fletcher Lane near Selah, WA \\
\hline 12498980 & Cowiche Creek at Weikel, WA \\
\hline 12502500 & Ahtanum Creek at Union Gap, WA \\
\hline 12505450 & Granger Drain at Granger, WA \\
\hline 12508400 & Satus Creek above Dry Creek near Toppenish, WA \\
\hline 12508480 & Dry Creek near Toppenish, WA \\
\hline 12508820 & Black Canyon Creek at Waneta Road near Sunnyside, WA \\
\hline 465647120265700 & Park Creek at S. Ferguson Road near Ellensburg, WA \\
\hline 465708120270500 & Caribou Creek at S Ferguson Road near Ellensburg, WA \\
\hline \multicolumn{2}{|c|}{ Central Nebraska Basins (CNBR) } \\
\hline 06767500 & Plum Creek near Smithfield, NE \\
\hline 06772000 & Wood River near Alda, NE \\
\hline 06773500 & Prairie Creek near Silver Creek, NE \\
\hline 06781800 & South Loup River near Callaway, NE \\
\hline 06784500 & Oak Creek near Dannebrog, NE \\
\hline 06788898 & Mira Creek near North Loup, NE \\
\hline 06795500 & Shell Creek near Columbus, NE \\
\hline 06800000 & Maple Creek near Nickerson, NE \\
\hline 403559099112201 & North Dry Creek at CR 742, Phelps County, NE \\
\hline
\end{tabular}


Table 1. Riparian mapping locations in study.-Continued

[CR, county road; DR, drain; JD, joint drain; SCBID, South Columbia Basin Irrigation District; SR, state road]

\begin{tabular}{|c|c|}
\hline U.S. Geological Survey station number & \multirow[b]{2}{*}{ 3asins (CNBR) -Continued } \\
\hline Central Nebraska Basins (CNBR)_Continued & \\
\hline 403948099160201 & South Channel Platte tributary near Odessa, NE \\
\hline 405041099460501 & Buffalo Creek near Lexington, NE \\
\hline 405129099493201 & Spring Creek at CR 761, Dawson County, NE \\
\hline 411320099154301 & Mud Creek near Mason City, NE \\
\hline 412103098234701 & Spring Creek near Wolbach, NE \\
\hline 412240097205901 & Clear Creek near Columbus, NE \\
\hline 412441098033901 & Timber Creek near Fullerton, NE \\
\hline 412512097055301 & Lost Creek near Schulyer, NE \\
\hline 412546096542001 & Skull Creek near Linwood, NE \\
\hline 412829097405601 & Looking Glass Creek near Genoa, NE \\
\hline 413311097171001 & Loseke Creek near Columbus, NE \\
\hline 413548098575901 & Dane Creek near Ord, NE \\
\hline 413850099402301 & Victoria Creek southeast of Milburn, NE \\
\hline 01484036 & Hudson Branch at Canterbury, DE \\
\hline 01484050 & Pratt Branch near Felton, DE \\
\hline 01484100 & Beaverdam Branch at Houston, DE \\
\hline 01484534 & Swan Creek near Millsboro, DE \\
\hline 01484640 & Unity Branch at Fairmount, DE \\
\hline 01484645 & Phillips Branch near Fairmount, DE \\
\hline 01484652 & Bundicks Branch near Cool Spring, DE \\
\hline 01485025 & Burnt Mill Branch near Pittsville, MD \\
\hline 01485030 & Aydylotte Branch at Pittsville, MD \\
\hline 01486100 & Andrews Branch near Delmar, MD \\
\hline 01487060 & Mifflin Ditch near Georgetown, DE \\
\hline 01487116 & Stony Branch at Hardscrabble, DE \\
\hline
\end{tabular}


Table 1. Riparian mapping locations in study.-Continued

[CR, county road; DR, drain; JD, joint drain; SCBID, South Columbia Basin Irrigation District; SR, state road]

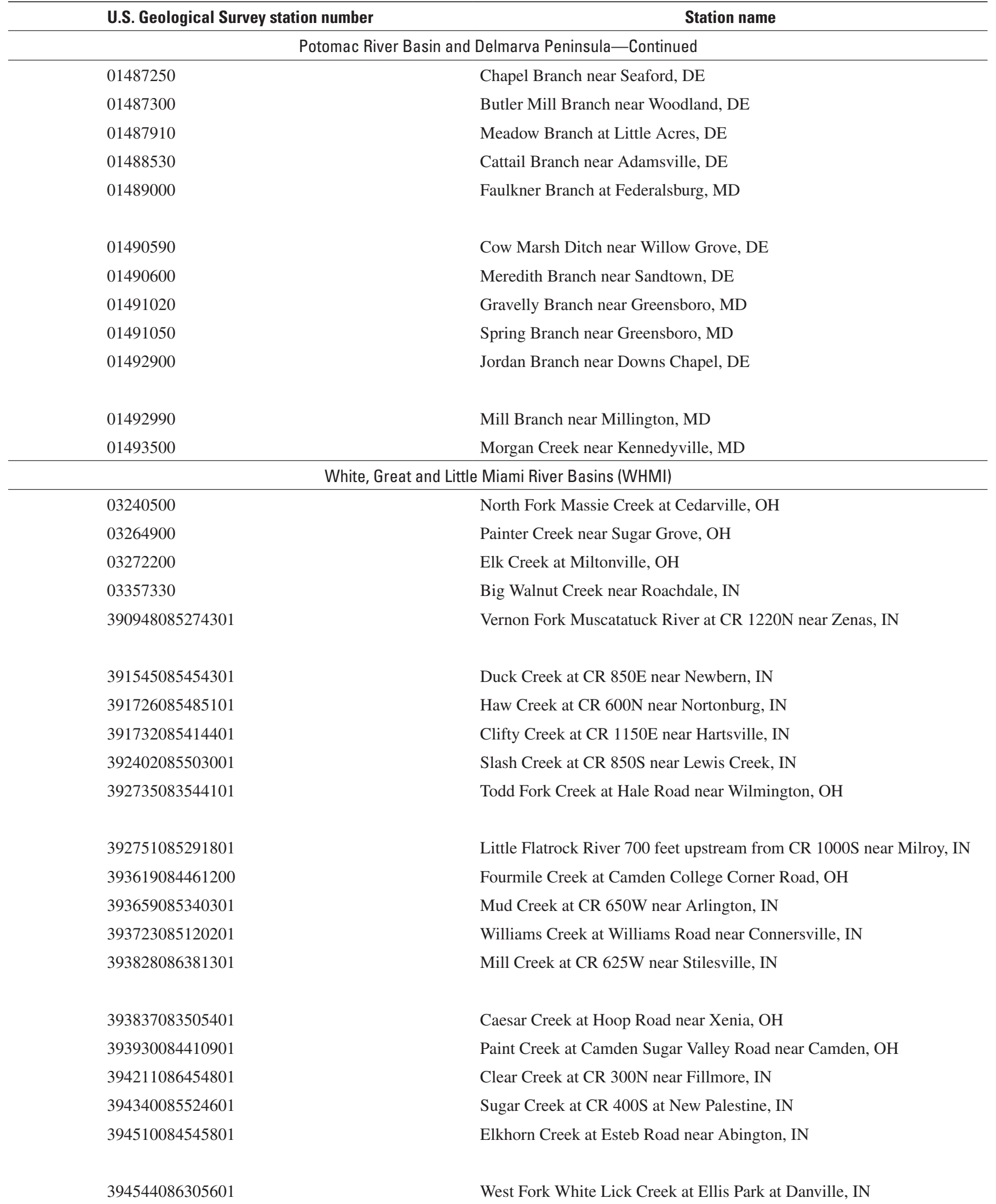


Table 1. Riparian mapping locations in study.-Continued

[CR, county road; DR, drain; JD, joint drain; SCBID, South Columbia Basin Irrigation District; SR, state road]

\begin{tabular}{cl}
\hline U.S. Geological Survey station number & \multicolumn{1}{c}{ Station name } \\
\hline 395121083561701 & White, Great and Little Miami River Basins (WHMI) \\
395327085190801 & Mud Run Creek at Hunter Road near Enon, OH \\
395350084353800 & $\begin{array}{l}\text { Flatrock River at CR 350E near New Castle, IN } \\
\text { Twin Creek at Euphemia Castine Road, OH }\end{array}$ \\
395623085090401 & West Fork Whitewater River at Hoover Road near Hagerstown, IN \\
395625084010101 & Honey Creek at New Carlisle Pike near New Carlisle, OH \\
400421084115601 & \\
400540084415601 & Spring Creek at Piqua Troy Road near Troy, OH \\
400806085455601 & West Branch Greenville Creek at Nashville Road near Greenville, OH \\
402901083482601 & Indian Creek at CR 200N near Hamilton, IN \\
\end{tabular}

Stream segments, with lengths equal to the logarithm of the basin area, were delineated upstream from the downstream end of the stream reach with the use of digital orthophoto quarter quadrangles (DOQQ) or selected from the high-resolution National Hydrography Dataset (NHD). Use of the NHD was necessary when the streams were not distinguishable in the DOQQ as was the case for most ACFB sites because of dense tree canopy. The analysis area for each stream segment was defined by a buffer beginning at the segment extending to 250 meters lateral to the stream segment. Delineation of LULC map units within stream segment buffers was conducted using on-screen digitizing of riparian LULC classes interpreted from the DOQQ. The riparian LULC units were mapped using a customized LULC classification system adapted for characterizing riparian zones (table 2). This classification system is a modified version of the classification strategy by Anderson and others (1976). National Wetlands Inventory (NWI) data were used to aid in wetland classification. Areal LULC datasets were produced for $25-\mathrm{m}$ and $50-\mathrm{m}$ buffers at the reach scale and 50-m, 100-m, 150-m, and 250-m buffers at the segment scale. Reach and segment longitudinal transect sampling lines offset from the stream reaches and segments were generated and partitioned into the underlying LULC types. The longitudinal samples yielded the relative linear extent and sequence of each LULC type within the riparian zone.

\section{Riparian Land Use/Land Cover Data}

The datasets described in this report are available directly for download from these Web links:

ArcInfo coverage;

ArcInfo interchange format (*.e00); and

ESRI shapefile.
Data available from these links are in .zip compressed format. WinZip ${ }^{\circledR}$ is a Windows-based compression utility. A program like this is needed to extract the data. A link to a trial copy of WinZip software is available at: http://www.winzip. com/downwz.htm (accessed October 2, 2007). Each link contains a compressed file containing geospatial data sets in one of three format types: (1) Environmental Systems Research Institute, Inc. (ESRI) ArcInfo coverages (Environmental Systems Research Institute, Inc., 2007); (2) ESRI ArcInfo export (.e00); or (3) ESRI shapefile (Environmental Systems Research Institute, Inc., 1998) format files.

ESRI distributes the GIS software ArcGIS, which is an integrated collection of GIS software products including ArcInfo. For more information on the ESRI, please refer to http://www.esri.com (accessed October 2, 2007). Coverage is the term used by ESRI (2007) for a vector-based digital map stored in ArcInfo (Environmental Systems Research Institute, Inc., 2007). Coverages consist of geographic features stored as points, lines or polygons, attribute tables accessible to the user, and tables that are used exclusively by the software. An ESRI shapefile consists of a main file, an index file, and a $\mathrm{dBASE}^{\circledR}$ format table. Each record in the main file describes a shape with a list of its vertices. In the index file, each record contains the offset of the corresponding main file record from the beginning of the main file. The dBASE table contains feature attributes with one record per feature and may contain additional information describing the feature.

The 12 geospatial datasets are detailed in the protocol (Johnson and Zelt, 2005) and are listed and described as follows:

1. lulc025r-riparian land use/land cover within $25 \mathrm{~m}$ of the stream reach (polygon);

2. lulc050r - riparian land use/land cover within $50 \mathrm{~m}$ of the stream reach (polygon); 
Table 2. Land-use/land-cover classification system for riparian areas.

[Modified from Anderson and others (1976); LU_CODE, land-use code used in digital data and tables; LULC, land use/land cover]

\begin{tabular}{lll}
\hline LU_CODE & LULC Class & \multicolumn{1}{c}{ Explanation } \\
\hline B & Barren land & Bare soil, sand, gravel deposit, rock outcrop \\
C & Cropland & Row crops, small grains, alfalfa, or other herbaceous crops \\
F & Farmstead & Farm dwelling, outbuildings, barnyards, livestock yards, or pens \\
G & Grassland & Grass, pasture, or herbaceous rangeland \\
O & Open water & Water bodies including ponds, lakes, streams, and canals \\
S & Shrubland & Shrubs, where able to distinguish \\
U & Urban/built-up land & Urban residential, commercial, transportation, or industrial land covers \\
W & Wetland & Both herbaceous and wooded wetlands \\
WV & Woody vegetation & Trees, shrubs, brushy rangeland (includes orchards and vineyards) \\
\hline
\end{tabular}

3. lulc050s-riparian land use/land cover within $50 \mathrm{~m}$ of the stream segment (polygon);

4. lulc100s_riparian land use/land cover within $100 \mathrm{~m}$ of the stream segment (polygon);

5. lulc150s_riparian land use/land cover within $150 \mathrm{~m}$ of the stream segment (polygon);

6. lulc250s — riparian land use/land cover within $250 \mathrm{~m}$ of the stream segment (polygon);

7. r_freq-frequency of gaps in woody vegetation land use/ land cover at the reach scale (arc);

8. reach—stream reaches ( $\operatorname{arc})$;

9. rmargin-longitudinal land use/land cover at the reach scale (arc);

10. s_freq-frequency of gaps in woody vegetation land use/ land cover at the segment scale (arc);

11. segment—-stream segments (arc); and

12. smargin-longitudinal land use/land cover at the segment scale (arc).

Available at each link is a compressed file containing a ReadME.txt file, metadata, and all 12 geospatial datasets in the following formats: ArcInfo coverage, ArcInfo interchange format (*.e00), and ESRI shapefile.

\section{References Cited}

Anderson, J.R., Hardy, E.E., Roach, J.T., and Witmer, R.E., 1976, A land use and land cover classification system for use with remote sensor data: U.S. Geological Survey Professional Paper 964, 28 p.
Environmental Systems Research Institute, 1998, ESRI Shapefile technical description: Redlands, Calif., accessed October 2, 2007 at http://www.esri.com/library/whitepapers/ $p d f$ s/shapefile.pdf.

Environmental Systems Research Institute, Inc., 2007, GIS dictionary: Redlands, Calif., accessed October 2, 2007, at http://support.esri.com/index.cfm?fa=knowledgebase. gisDictionary.gateway

Fitzpatrick, F.A., Waite, I.A., D’Arconte, P.J., Meador, M.R., Maupin, M.A., and Gurtz, M.E.,1998, Revised methods for characterizing stream habitat in the National Water-Quality Assessment Program: U.S. Geological Survey WaterResources Investigations Report 98-4052, 67 p.

Frankforter, J.D., Johnson, M.R., and Zelt, R.B., 2003, Nutrient concentration gradients and biological response in Central Nebraska streams in AWRA 2003 Spring Specialty Conference, May 12-14, 2003, Kansas City, Missouri, Proceedings: Middleburg, Va., American Water Resources Association, CD-ROM only, available on Web, accessed September 18, 2007, at http://ne.water.usgs.gov/Nawqa/ pubs/awra_kcmo2003_proceedgs/JillFrankforter673.pdf

Frissell, C.A., Liss, W.J., Warren, C.E., and Hurley, M.D., 1986, A hierarchical framework for stream habitat classification-viewing streams in a watershed context: Environmental Management, v. 10, p. 199-214.

Gilliom, R.J., Hamilton, P.A., and Miller, T.L., 2001, The National Water-Quality Assessment Program-entering a new decade of investigations: U.S. Geological Survey Fact Sheet 071-01, 6 p.

Johnson, M.R., and Zelt, R.B., 2005, Protocols for mapping and characterizing land use/land cover in riparian zones: U.S. Geological Survey Open-File Report 2005-1302, 22 p. 
U.S. Environmental Protection Agency, 2002, Aggregations of Level III Ecoregions for National Nutrient Assessment \& Management Strategy: Corvallis, Oregon, U.S. Environmental Protection Agency, National Health and Environmental Effects Laboratory, vector digital data.
Vogelmann, J.E., Howard, S.M., Yang, L., Larson, C.R., Wylie, B.K., and Van Driel, N., 2001, Completion of the 1990's National Land Cover Dataset for the conterminous United States from Landsat Thematic Mapper data and ancillary data sources: Photogrammetric Engineering and Remote Sensing, v. 67, p. 650-662.

Publishing support provided by:

Rolla Publishing Service Center

For more information concerning this publication, contact:

Director, USGS Nebraska Water Science Center

5231 S. 19 Street

Lincoln, NE 68512

(402) 328-4100

Or visit the Nebraska Water Science Center Web site at: http://ne.water.usgs.gov 


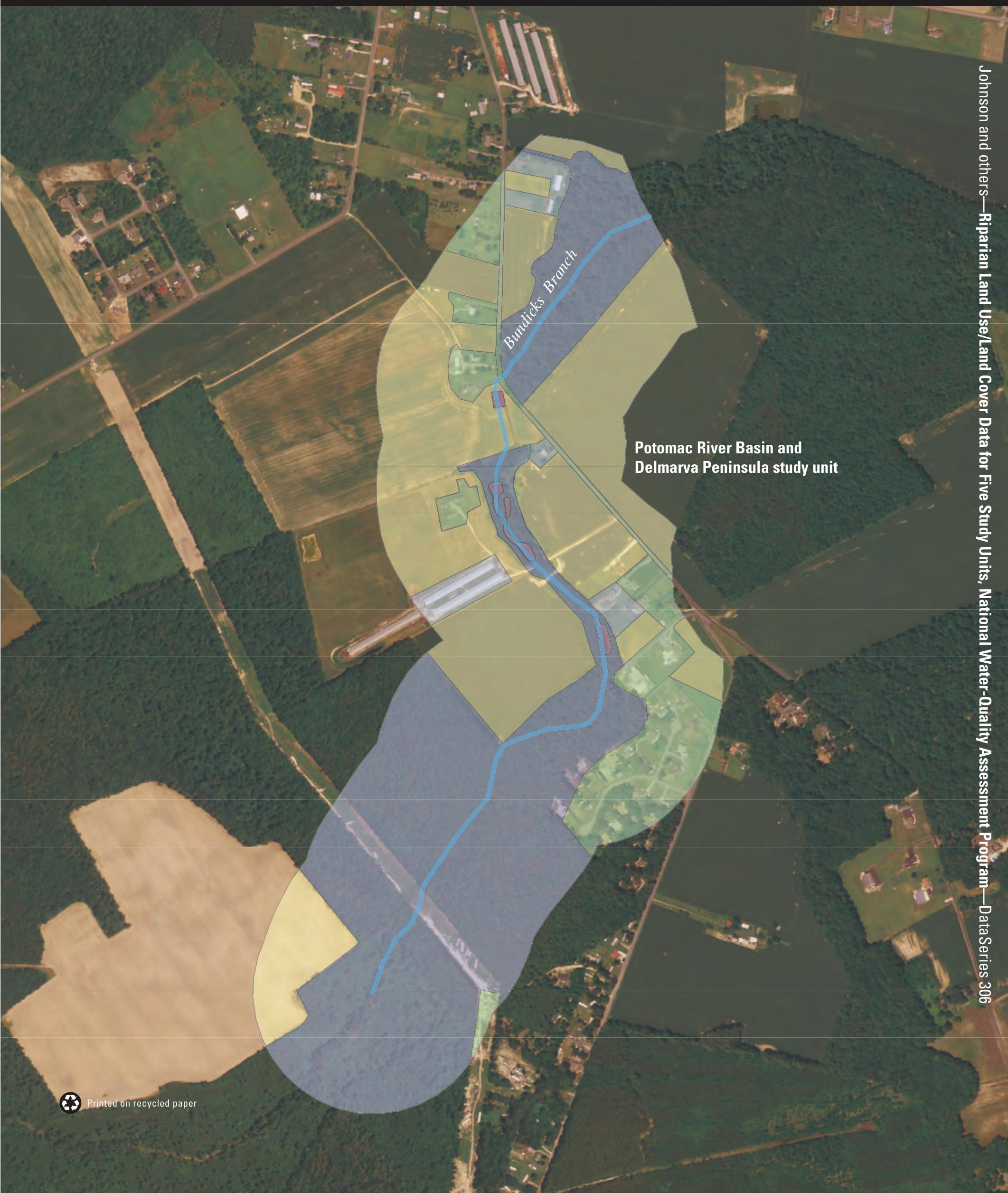

